\title{
Proximate Composition and Biological Assay of Two Mustard Species (Brassica nigra (L.) K. Koch and Brassica tournefortii Gouan) in Libya
}

\author{
Salem Mousbah Khalifa* \\ Department of Biology, College of Education, University of Al-Jufra, Libya \\ *Corresponding author
}

\section{A B S T R A C T}

\section{Keywords}

Allelopathy, Antioxidants,

Brassica,

Phytotoxicity, Weeds

Article Info

Accepted:

12 December 2020

Available Online:

10 January 2021
People will still be looking for new sources of food, feed, and medicine to face the challenges of malnutrition and population growth. In this study, the proximate composition, minerals, bioactive-secondary metabolites, and biological assay (antioxidants and allelopathic activities) of two Brassica species collected from the coastal region of Misurata, Libya: Brassica nigra(L.) K. Koch and Brassica tournefortii Gouan were investigated. The shoot of Brassica tournefortii had the highest contents of moisture $(22.19 \%)$, total ash $(16.90 \%)$, crude fibers $(25.40 \%)$, crude fat $(5.5 \%)$, sodium $(45.10 \mathrm{mg}$ $\mathrm{g}^{-1}$ dry weight), potassium (38.80 mg g $\mathrm{m}^{-1}$ dry weight), calcium (22.40 mg g $\mathrm{m}^{-1}$ dry weight), magnesium (13.50 $\mathrm{mg} \mathrm{g}^{-1}$ dry weight), total phenols $\left(34.50 \mathrm{mg} \mathrm{g}^{-1}\right.$ dry weight) and flavonoids (18.78 $\mathrm{mg} \mathrm{g}^{-1}$ dry weight). While, the shoot of Brassica nigra attained the greatest values of crude protein $(10.30 \%)$, tannins (10.4 $\mathrm{mg} \mathrm{g}^{-1}$ dry weight), alkaloids (2.09 $\mathrm{mg} \mathrm{g}^{-1}$ dry weight), and saponins (1.50 $\mathrm{mg} \mathrm{g}^{-1}$ dry weight). Regarding antioxidants activity, the extract of $B$. tournefortii shoots had a high IC50 value $\left(0.32 \mathrm{mg} \mathrm{ml}^{-1}\right)$ than the shoot of B. nigra $\left(0.37 \mathrm{mg} \mathrm{ml}^{-1}\right)$, but lower than catechol $\left(0.18 \mathrm{mg} \mathrm{ml}^{-1}\right)$. The methanolic extracts of B. tournefortii shoots and roots had the highest germination inhibition percentages (88.1 and $82.32 \%$, respectively) for Chenopodium murale seeds. The extracts of $B$. tournefortii shoots displayed the highest inhibition percentage for plumule and radicle growths of Chenopodium murale(93.17and $96.21 \%$, respectively). The highest allelopathic activity of B. tournefortii may be attributed to the high contents of total phenols and flavonoids as compared with $B$. nigra. The present work suggests that Brassica tournefortii is a good candidate as a nutritional, antioxidant source, andan eco-friendly bioherbicide against a noxious weed Chenopodium murale.

\section{Introduction}

Wild plants play a vital role in human life as sources of food, feed, dyes, fuels, ethnomedicine, phytoremediation, etc. (Zimdahl, 2007). The importance of these plants is attributed to their richness in proximate primary composition (carbohydrates, proteins, fibers, fats, andminerals), and bioactive secondary metabolites (total phenols, flavonoids, tannins, alkaloids, saponins, etc.) (Newman and Cragg, 2007; Kumari and Kakkar, 2008). The biological activities of plants include many aspects, for example, antioxidant activity, allelopathic, antimicrobial, cytotoxic 
effects, and other physiological effects on the living organisms.

Brassica is the most significant genus in Family Brassicaceae which includes 350 genera and ca. 3500 species. Species of genus Brassica had worldwide importance due to their medicinal, nutritional and pharmaceutical benefits. Globally, most Brassica species are cultivated for many purposes, for example, as oilseed crops, vegetables, medicinal and animal forage (Nawaz et al., 2018). Following soybean and palm, Brassica spp. are the third supply for edible oils and vegetables. Brassica species are a rich source of phenolics, flavonoids, alkaloids, glucosides, and terpenoids. Therefore, these plants had antioxidant activities through free radicle scavenging activity, and metal-reducing and chelating. Among different species of the genus Brassica, Brassi canigra and Brassica tournefortti are also antioxidant and phytochemical-rich species. The different organs (root, stem, leaves, seeds) of Brassica plants are consumed as vegetables or oil, food, and for medicinal purposes (Nawaz et al., 2018).

Brassica nigra (L.) K. Koch (black mustard) is an annual herbaceous plant with stiff hairs. This plant grows naturally as a weed within the winter field crops and along roads of the Mediterranean coastal region of Libya. It is widely distributed in Africa, China, Europe, and the USA (Al-Snafi, 2015).

The cultivation of B. nigra is attributed to its importance as a source of essential oil, mustard flour, condiment, honey producers, and various medicinal purposes (i.e. stimulant, diuretic, rubefacient, arthritis, edema, emetic, hair growth, colds, pneumonia, headaches, anticancer, anthelmintic, etc.) (Heidari and Abbsifard, 2002; Udin et al., 2020). This plant is also had antibacterial activities (Gomezde Saravia et al., 1998; Danlami et al., 2016).

Brassica tournefortii Gouan (Sahara mustard) is an annual erect herb native tothe Mediterranean coast and arid deserts of the Middle East and North Africa (Trader et al., 2006). Medicinally, it is a good source of antioxidants, polyphenols, nutrients and nutraceuticals (Rahmani et al., 2020). Similar to other Brassica spp, B. tournefortii is widely used for medicinal, culinary and ecological purposes (Matthäus and Özcan 2009). Also, some previous studies (e.g. Minnich and Sannders, 2000; Curto et al., 2006; Rahmani et al., 2019) demonstrated the use of $B$. tournefortii in traditional meals, as antiparasitic and as anti-breast cancer.On contrary, B. tournefortii becomes a problematic invasive weed in Australia (Mahajan et al., 2020).Moreover, this plant is drought-tolerant and produces numerous long-lived seeds that can persist viable in the soil for several years (Mashaly et al., 2015).

In this study, we assumed Brassica rapa and Brassica tournefortti are considered excellent candidates as nutritional and pharmaceutical sources. Therefore, the main objectives of the current study were to 1) estimate the proximate composition of the shoots and roots of two Brassica species, 2) know the concentration of bioactive secondary metabolites and 3) assay antioxidants and allelopathic activities.

\section{Materials and Methods}

\section{Determination of proximate composition}

Two Brassica spp. were collected from the coastal region of Misurata, Libya, then cleaned with running-water to remove debris, divided into shoots and roots, and finally airdried before grinding. Moisture content, total ash, crude fiber, crude protein, crude fat and 
total carbohydrates were estimated according to the protocol of the Association of Official Analytical Chemists (AOAC, 2000).

\section{Minerals analysis}

The macroelements $\left(\mathrm{Na}^{+}\right.$and $\left.\mathrm{K}^{+}\right)$and $\left(\mathrm{Ca}^{++}\right.$ and $\mathrm{Mg}^{++}$) of shoots and roots of Brassica nigra and $B$. tournefortii were analyzed after heating with $\mathrm{HNO}_{3}$ by using a flame photometer (Hanchen FP)and atomic absorption spectrometer (A Perkin-Elmer), respectively (AOAC, 2000).

\section{Bioactive secondary metabolites}

For both shoots and roots of the two studied Brassica spp, total phenols and tannins were estimated in ethanolic plant-extractsby using Folin and vanillin- $\mathrm{HCl}$ reagents, respectively (Sadasivam and Manickam, 2008). Flavonoids content was determined by using the $\mathrm{AlCl}_{2}$ method (Boham and KocipaiAbyazan, 1974). Alkaloids content was gravimetrically estimated using $\mathrm{NH}_{4} \mathrm{OH}$ solution (Harborne, 1984). Saponins content was estimated according to Obadoni and Ochuko (2002).

\section{Biological activities}

\section{Antioxidant activity using DPPH scavenging activity}

The antioxidant activity of shoot and roots of two Brassica spp. were valued via scavenging activity of 1,1-diphenyl-2-picrylhydrazyl (DPPH). The half inhibitory concentration $\left(\mathrm{IC}_{50}\right)$ of each extract to reduce DPPH was calculated (Lim and Quah, 2007). Catechol was considered for comparison.

\section{Allelopathic activity}

To study the allelopathic activity of the two studied Brassica species, seeds of a nuisance weed Chenopodium murale L. was collected from field crops. Different methanolic concentrations of $8,6,4$ and $2 \%$ from shoots and roots of Brassica species were prepared from stock extract $(10 \% \mathrm{w} / \mathrm{v})$. After sterilization of Chenopodium murale seeds, the methanolic extracts of Brassica species were tested against seed germination (germination inhibition percent), plumule and radicle lengths (growth inhibition percent) of C. murale until constant readings for germination and growth data (Hegazy,1997; Uremis et al., 2005).

\section{Statistical analysis}

The significance between data were tested using one-way ANOVA in XLSTAT program v. 2018.

\section{Results and Discussion}

Proximate composition, minerals and bioactive secondary metabolites

The primary proximate analysis is among the most important indicators that refer to the possibility of using any plant as a food or forage and categorizing nutritional facts (Keyata et al., 2020). The proximate composition, minerals and bioactive secondary metabolites of shoot and roots of Brassica nigra and B.tournefortii are shown in Table 1.

The moisture contents for shoots of $B$. tournefortii and $B$. nigra were 22.19 and $21.10 \%$, respectively. The value of moisture content is an indicator of food quality and degree of susceptibility for deterioration and storage period. The results showed that the shoots and roots of the study Brassica species had low moisture content as compared with aerial parts of related species Girgir and Figl (87.39 and 94\%, respectively) (Keyata et al., 2020). This finding addressed the resistance 
of the aerial-parts of Brassica species against microbial spoilage.

Total ash showed a significant difference among shoot and roots of the Brassica species. Shoots of $B$. tournefortti had the highest value $(16.90 \%)$ and roots of $B$. nigra had the lowest value $(9.50 \%)$. This finding agreed with the ash content of leaves of radish from Egypt (Magied et al., 2016) and proved the highest mineral content. The aerial parts of $B$. tournefortti had significantly higher fiber content $(25.40 \%)$ similar to values in leaves of Fig.l. The consumption of fiber-rich plants reduces the risk of colon cancer, improves digestion and removal of wastes (DeVries et al., 2001). Based on dry matter, the protein content of the two Brassica species showed a significant variation at $\mathrm{p}<$ 0.05 . Sufficient protein content in the diet keeps optimal growth.

The highest protein content was attained in the shoots of $B$. nigra $(10.30 \%)$ but the lowest in the roots of B. tournefortii (7.11\%).Similar results were also reported for dried leaves of Figl and Moringa (between 24 and 26 g/100 g) (Mikore and Mulugeta, 2017; Keyata et al., 2020).

Table.1 Proximate composition, minerals and bioactive secondary metabolites of shoots and roots of Brassica species. Different letters in the same row are significantly different at $\mathrm{p}<0.05$

\begin{tabular}{|c|c|c|c|c|}
\hline \multirow[t]{2}{*}{ Parameter } & \multicolumn{2}{|c|}{ Brassica nigra } & \multicolumn{2}{|c|}{ Brassicatournefortii } \\
\hline & Shoot & Root & Shoot & Root \\
\hline \multicolumn{5}{|c|}{ Proximate composition (\%) } \\
\hline Moisture content & $21.10 \pm 1.4^{\mathrm{a}}$ & $18.50 \pm 0.9^{b}$ & $22.19 \pm 2.0^{\mathrm{a}}$ & $18.9 \pm 0.5^{b}$ \\
\hline Total ash & $13.40 \pm 3.0^{\mathrm{a}}$ & $9.50 \pm 2.4^{\mathrm{a}}$ & $16.90 \pm 1.0^{\mathrm{b}}$ & $10.18 \pm 1.5^{b}$ \\
\hline Crude fiber & $20.20 \pm 0.8^{\mathrm{a}}$ & $18.80 \pm 0.9^{\mathrm{a}}$ & $25.40 \pm 2.0^{\mathrm{b}}$ & $22.89 \pm 1.8^{\mathrm{ab}}$ \\
\hline Crude protein & $10.30 \pm 2.5^{\mathrm{a}}$ & $9.67 \pm 1.3^{\mathrm{a}}$ & $8.58 \pm 0.5^{\mathrm{b}}$ & $7.11 \pm 1.2^{\mathrm{ab}}$ \\
\hline Crude fat & $4.80 \pm 0.5^{\mathrm{a}}$ & $4.1 \pm 0.3^{\mathrm{a}}$ & $5.50 \pm 0.9^{\mathrm{b}}$ & $5.0 \pm 0.6^{\mathrm{b}}$ \\
\hline Total carbohydrates & $50.4 \pm 1.5^{\mathrm{a}}$ & $58.23 \pm 1.2^{b}$ & $46.83 \pm 2.1^{\mathrm{a}}$ & $58.81 \pm 2.0^{\mathrm{b}}$ \\
\hline \multicolumn{5}{|c|}{ Minerals (mg g g $^{-1}$ dry weight) } \\
\hline Sodium $\left(\mathrm{Na}^{+}\right)$ & $38.90 \pm 0.6^{\mathrm{a}}$ & $28.60 \pm 0.8^{\mathrm{b}}$ & $45.10 \pm 2.5^{\mathrm{c}}$ & $34.20 \pm 0.1^{\mathrm{d}}$ \\
\hline Potassium $\left(\mathbf{K}^{+}\right)$ & $29.20 \pm 1.5^{\mathrm{c}}$ & $18.23 \pm 0.5^{b}$ & $38.80 \pm 0.4^{\mathrm{a}}$ & $29.70 \pm 2.0^{c}$ \\
\hline Calcium $\left(\mathbf{C a}^{++}\right)$ & $18.50 \pm 0.7^{\mathrm{a}}$ & $17.80 \pm 0 . .^{4 a}$ & $22.40 \pm 0.9^{\mathrm{b}}$ & $18.60 \pm 1.0^{\mathrm{a}}$ \\
\hline Magnesium $\left(\mathrm{Mg}^{++}\right)$ & $8.20 \pm 0.4^{\mathrm{a}}$ & $8.0 \pm 0.1^{\mathrm{a}}$ & $13.50 \pm 0.3^{b}$ & $13.0 \pm 0.8^{b}$ \\
\hline \multicolumn{5}{|c|}{ Secondary metabolites (mg g ${ }^{-1}$ dry weight) } \\
\hline Total phenols & $26.12 \pm 1.5^{\mathrm{a}}$ & $18.4 \pm 1.3^{b}$ & $34.50 \pm 2.6^{\mathrm{c}}$ & $20.50 \pm 1.3^{\mathrm{ab}}$ \\
\hline Tannins & $10.4 \pm 1.8^{\mathrm{a}}$ & $6.40 \pm 0.5^{\mathrm{b}}$ & $9.11 \pm 1.0^{\mathrm{a}}$ & $7.60 \pm 1.9^{\mathrm{ab}}$ \\
\hline Flavonoids & $12.90 \pm 2.0^{c}$ & $8.21 \pm 1.0^{\mathrm{a}}$ & $18.78 \pm 2.0^{b}$ & $16.80 \pm 1.5^{\mathrm{d}}$ \\
\hline Alkaloids & $2.09 \pm 0.3^{\mathrm{a}}$ & $1.11 \pm 0.1^{b}$ & $1.10 \pm 0.3^{\mathrm{b}}$ & $1.40 \pm 0.0^{\mathrm{b}}$ \\
\hline Saponins & $1.50 \pm 0.1^{\mathrm{a}}$ & $1.03 \pm 0.0^{\mathrm{ab}}$ & $1.30 \pm 0.0^{\mathrm{a}}$ & $1.10 \pm 0.0^{\mathrm{b}}$ \\
\hline
\end{tabular}


Fig.1 IC50 values $\left(\mathrm{mg} \mathrm{ml}^{-1}\right)$ of shoots and roots of Brassica nigra and Brassica tournefortii. IC50 of catechol was $0.18 \mathrm{mg} \mathrm{ml}^{-1}$

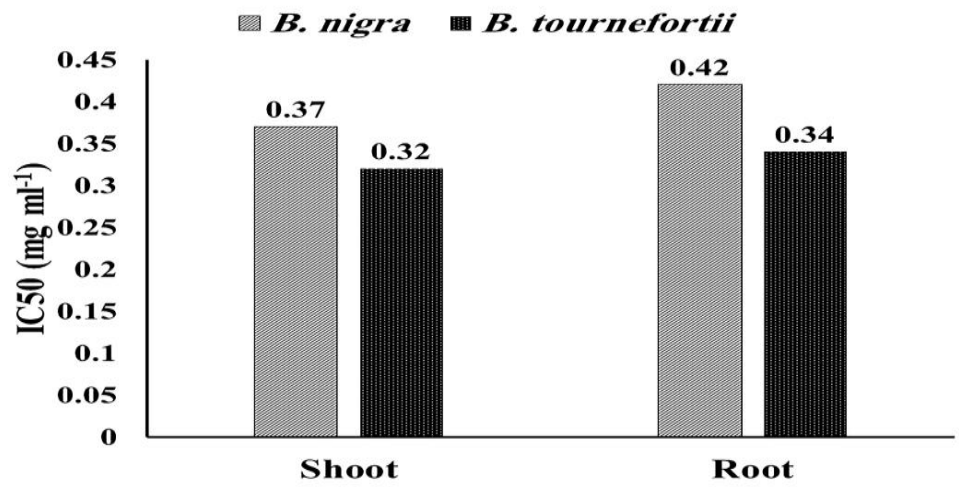

Fig.2 Allelopathic activity (mean values of inhibition percentages \pm SE) of methanolic extracts from shoot and roots of B. nigra and B.tournefortii against a) seed germination, b) plumule growth and c) radicle growth of Chenopodium murale

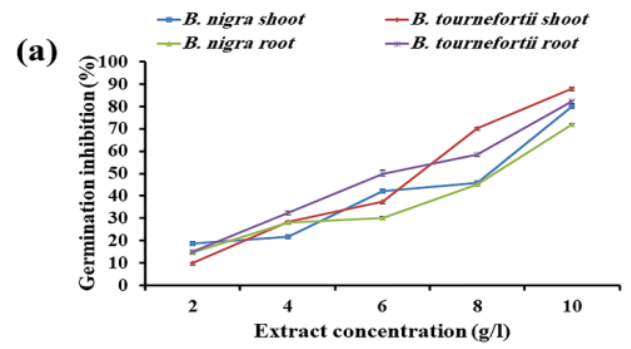

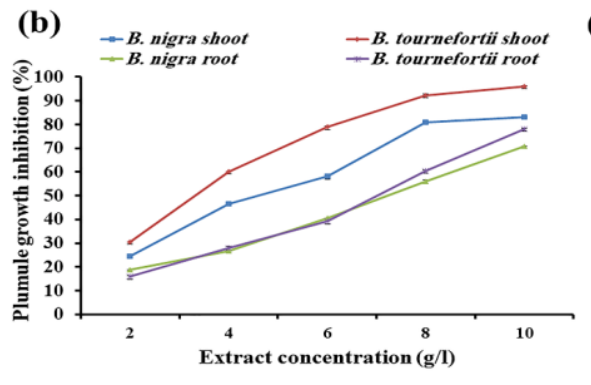

The shoot and roots of $B$. tournefortii showed relatively great values of crude fats (5.50 and $5 \%$, respectively) than shoots and roots of $B$. nigra (4.80 and $4.1 \%$, respectively). Rios et al., (2014) addressed the importance of raw fats and oils for modified-food products, such as bakery, sauces, margarine and confectionery. As compared with the study Brassica species, Kwon et al., (2020) reported a low value of crude protein $(1.5 \%)$ in Brassica juncea cultivars in Korea. The

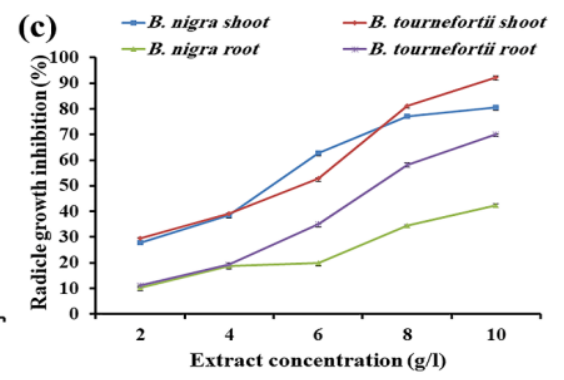

percent of carbohydrates was significantly different between shoots and roots of the two Brassica species. Roots of B. tournefortii attained a comparable value (58.81\%) with roots of B. nigra (58.23\%). High levels of carbohydrates provide adequate energy for the human/animal and the plant itself.

The minerals content has a crucial role in the human body as it helps to build strong bones and performance of various metabolic 
activities. The concentration of macroelements $\left(\mathrm{Na}^{+}, \mathrm{K}^{+}, \mathrm{Ca}^{++}\right.$and $\left.\mathrm{Mg}^{++}\right)$is significantly differed and displayed in Table 1. The shoots of $B$. tournefortii had the highest values of sodium $\left(45.10 \mathrm{mg} \mathrm{g}^{-1} \mathrm{dry}\right.$ weight), potassium ( $38.80 \mathrm{mg} \mathrm{g}^{-1} \mathrm{dry}$ weight), calcium (22.40 $\mathrm{mg} \mathrm{g}^{-1}$ dry weight) and magnesium (13.50 $\mathrm{mg} \mathrm{g}^{-1}$ dry weight). The minerals content in the studied Brassica spp is in close agreement with edible parts of Figl and Girgir (Keyata et al., 2020). Sodium is an essential element for physiological activities and homeostasis, but an excess of sodium in a diet causes a rise in blood pressure (Farquhar et al., 2015). Potassium-, calcium- and magnesium-rich-plants can help people who suffer from the deficiency of these elements in their body and also improve bone building (Trumbo et al., 2001; Sodamade et al., 2013).

The results of bioactive secondary metabolites contents of shoots and roots of Brassica species are shown in Table 1 . The shoot of $B$. tournefortii had significantly high total phenols and flavonoids levels(34.50 and $18.78 \mathrm{mg} \mathrm{g}^{-1}$, respectively) than the shoot of B. nigra (26.12 and $12.90 \mathrm{mg} \mathrm{g}^{-1}$, respectively). On the other hand, the shoot of $B$. nigra attained the highest contents of tannins (10.4 $\left.\mathrm{mg} \mathrm{g}^{-1}\right)$, alkaloids $\left(2.09 \mathrm{mg} \mathrm{g}^{-1}\right)$ and saponins $\left(1.50 \mathrm{mg} \mathrm{g}^{-1}\right)$. Phenolics play a key role in eliminating cardiovascular diseases, diabetes and cancers (Santos-Buelga et al., 2019).

This finding indicates that, the shoots and roots of two Brassica species had great phenolic compounds as compared to leaves of Figl and Moringa (26.3 and $2.53 \mathrm{mg} \mathrm{g}^{-1}$, respectively) (Saha et al., 2015; Keyata et al., 2020). The flavonoids, alkaloids, tannins and saponins below toxicity level are known to have therapeutic activities such as anti-viral, anti-malarial and anti-tumor properties(Roy, 2017; Keyata et al., 2020).

\section{Biological activities}

\section{Antioxidants assay by DPPH free radicle scavenging activity}

The free radicle 1, 1-diphenyl-2picrylhydrazyl (DPPH) is widely used for an assay of the radicle scavenging activity of plant extracts. The scavenging activity on DPPH is expressed as IC50 which denotes the concentration of the extract required to hinders the DPPH by 50\% (Figure 1).

The extract of $B$. tournefortii shoots had high IC50 value $\left(0.32 \mathrm{mg} \mathrm{ml}^{-1}\right)$ than the shoot of $B$. nigra $\left(0.37 \mathrm{mg} \mathrm{ml}^{-1}\right)$. A similar trend was observed for root extracts of both studied Brassica species. All extracts showed higher values than catechol $\left(\mathrm{IC} 50=0.18 \mathrm{mg} \mathrm{ml}^{-1}\right.$ ). The antioxidant properties of Brassica species were confirmed by many previous studies (Heimler et al., 2007; Fernandes et al., 2007; Li et al., 2012; Xiao et al., 2018; Favela-González et al., 2020). The antioxidant potential of Brassica species is attributed to phenolic compounds, flavonoids and glucosinolates (Aires et al., 2011).

\section{Allelopathic activity}

The allelopathic activity of methanolic extracts of shoots and roots of B. nigra and $B$. tournefortii against germination and growth of Chenopodium murale is shown in Figure 2. In general, the inhibition percentage was concentration dependent, by increasing extract concentration, the inhibition percent for germination and seedling growth increases. The methanolic extracts of $B$. tournefortii shoots and roots had the highest inhibition percentages (88.1 and $82.32 \%$, respectively) for $C$. murale seed germination after 15 days of treatment (Figure 2a).

Regarding plumule inhibition, the methanolic extracts take the following sequence: $B$. 
tournefortii shoot $(93.17 \%)>B$. nigra shoot $(83.25 \%)>B$. tournefortii root $(78.16 \%)>B$. nigra root $(70.89 \%)$ (Figure $2 b)$. On the other hand, the methanolic extracts of $B$. tournefortii showed the highest inhibition percent $(96.21 \%)$ for the radicle growth of $C$. murale (Figure 2c). The highest allelopathic of $B$. tournefortii may be attributed to the high contents of total phenols and flavonoids as compared with $B$. nigra. This finding in close agreement with Bones and Rossiter (1996) who reported the allelopathic potentials of Brassica species.Halkier and Gershenzon (2006) and Blum (2011)displayed that, Brassica species contain allelochemicals (phenolic compounds, flavonoids, tannins) that are released to the environment and can affect the germination and growth of other species. Twaha and Turk (2003) reported that, B. nigrahadallelo chemicals that minimize the germination and growth of other plant species. The mechanism of allelochemicals for germination and growth inhibition may be due to their effect on cell division, oxidative enzymes, protein synthesis or membrane permeability(Chou, 2006).

In conclusion, brassica tournefortii had high proximate constituents (moisture, total ash, crude fibers, crude fat, and carbohydrates), minerals (sodium, potassium, calcium, and magnesium) and bioactive secondary metabolites (total phenols and flavonoids) as compared with Brassica nigra. Moreover, $B$. tournefortii shoot had high antioxidant activity and allelopathic effect against the nuisance weed Chenopodium murale.The present study suggests that, Brassica tournefortii is a good candidate as nutritional, antioxidant sources and an eco-friendly bioherbicide.

\section{References}

Aires, A., Fernandes, C., Carvalho, R., Bennett, R. N., Saavedra, M. J., and
Rosa, E. A. (2011). Seasonal effects on bioactive compounds and antioxidant capacity of six economically important Brassica vegetables. Molecules. 16(8): 68166832.

Al-Snafi, A. E. 2015. The pharmacological importance of Brassica nigra and Brassicarapa grown in Iraq. J. Pharm. Biol. 5(4): 240-253.

AOAC 2000. Association of Official Analytical Chemists. Official Methods of Analysis (Vol. II 17th edition) of AOAC International. Washington, DC, USA.

Blum, U. 2011. Plant-plant allelopathic interactions. In Plant-Plant Allelopathic Interactions. Springer, Dordrecht.

Boham, B. A., and Kocipai-Abyazan, R. 1974. Flavonoids and condensed tannins from leaves of Hawaiian Vaccinium vaticulatum and $V$. calycinium. Pacific Sci. 48(4): 458463.

Bones, A. M., and Rossiter, J. T. 1996. The myrosinase-glucosinolate system, its organisation and biochemistry. Physiol. Plant. 97(1): 194-208.

Chou, C. H. 2006. Introduction to allelopathy. In Allelopathy. Springer, Dordrecht.

Curto G., Dallavalle, E., Matteo, R., and Lazzeri, L. 2016.Biofumigant effect of new defatted seed meals against the southern root-knot nematode, Meloidogyne incognita. Ann. Appl. Biol. 2(169):17-26.

Danlami, U., OrishadipeAbayomi, T.,and Lawal, D. R. 2016. Phytochemical, nutritional and antimicrobial evaluations of the aqueous extract of Brassicanigra (Brassicaceae) seeds. Am. J. Appl. Chem. 4(4), 161-163.

DeVries, J. W., Camire, M. E., Cho, S., Craig, S., Gordon, D., Jones, J. M., andTungland, B. C. 2001. The 
definition of dietary fiber. Cereal Food World. 46(3): 112-129.

Farquhar, W. B., Edwards, D. G., Jurkovitz, C. T., and Weintraub, W. S. 2015. Dietary sodium and health: more than just blood pressure. J. Am. Coll.Cardiol. 65(10): 1042-1050.

Favela-González, K. M., HernándezAlmanza, A. Y.,and Fuente-Salcido, N. M. 2020. The value of bioactive compounds of cruciferous vegetables (Brassica) as antimicrobials and antioxidants: A review. J. Food Biochem. 44(10), e13414.

Fernandes, F., Valentão, P., Sousa, C., Pereira, J. A., Seabra, R. M., and Andrade, P. B. 2007. Chemical and antioxidative assessment of dietary turnip (Brassicarapa var. rapa L.). Food Chemistry. 105(3): 1003-1010.

Gomezde Saravia, S. G., and Gaylarde, C. C. 1998. The antimicrobialactivity of an extract of Brassica nigra. Biodet. Biodegrad. 41: 145-148.

Halkier, B. A., and Gershenzon, J. 2006. Biology and biochemistry of glucosinolates. Annu. Rev. Plant Biol. 57: 303-333.

Harborne, J. B. 1984. Methods of Plant Analysis. In Phytochemical methods (pp. 1-36). Springer, Dordrecht.

Hegazy, A. K. 1997. Allelopathic effect of Glossone maedula in Qatar. Allelopathic J. 4: 133-138.

Heidari, M. R., and Abbsifard, M. 2002. Evaluation of the analgesiceffect of Brassica nigra in mice. J. Mazandaran Univ. Med. Sci. 12: 18-26.

Heimler, D., Isolani, L., Vignolini, P., Tombelli, S., and Romani, A. 2007. Polyphenol content and antioxidative activity in some species of freshly consumed salads. J. Agric.Food Chem. 55(5): 1724-1729.

Keyata, E. O., Tola, Y. B., Bultosa, G., and Forsido, S. F. 2020. Proximate, mineral, and anti-nutrient compositions of underutilized plants of Ethiopia: Figl (Raphanus sativus L.), Girgir (Erucasativa L) and Karkade (Hibiscus sabdariffa): Implications for in-vitro mineral bioavailability. Food Res. Int. 137, 109724.

Kumari, A., and Kakkar, P. 2008. Screening of antioxidant potential of selected barks of Indian medicinal plants by multiple in vitro assays. Biomed. and Environ. Sci. 21(1): 24-29.

Kwon, H. Y., Choi, S. I., Park, H. I., Choi, S. H., Sim, W. S., Yeo, J. H., and Lee, O. H. 2020. Comparative analysis of the nutritional components and antioxidant activities of different Brassica juncea cultivars. Foods. 9(6): 840.

Li, H., Deng, Z., Zhu, H., Hu, C., Liu, R., Young, J. C., and Tsao, R. 2012. Highly pigmented vegetables: Anthocyanin compositions and their role in antioxidant activities. Food Res. Int. 46(1): 250-259.

Lim, Y. Y., andQuah, E. P. 2007. Antioxidant properties of different cultivars of Portulacaoleracea. Food Chem. 103(3): 734-740.

Magied, M. M. A., Alian, A. M., Haerrdy, L., and Hussein, M. T. 2016. The protective effect of white and red radish as hypoglycemic and hypocholesterolemic agents. J. Pharm. Biol. Sci. 11(3): 51-61.

Mahajan, G., Singh, R., and Chauhan, B. S. 2020. Biology of Brassica tournefortii in the northern grains region of Australia. Crop Pasture Sci. 71(3): 268-277.

Mashaly, I., Abdelaal M., andDawood N. 2015. Floristic composition and vegetation analysis and species diversity of some Brassica species associates in North of Nile Delta region, Egypt. Catrina. 14:45-52.

Matthäus, B., and Özcan, M. M. 2009. 
Chemical evaluation of some paprika (Capsicum annuum L.) seed oils. Eur J. Lipid Sci. Technol. 111:1249-1254.

Mikore, D., and Mulugeta, E. 2017. Determination of proximate and mineral compositions of Moringa oleifera and Moringa stenopetala leaves cultivated in Arbaminch Zuria and Konso, Ethiopia. Afr. J.Biotechnol. 16(15): 808-818.

Minnich, R., and Sanders, A. 2000.Brassica tournefortii. In: Bossard C. C., Randall J. M., Hochovsky M. M. (eds) Invasive plants of California's wildlands. University of California Press, Berkeley.

Nawaz, H., Shad, M. A., and Muzaffar, S. 2018. Phytochemical composition and antioxidant potential of Brassica. In: Brassica Germplasm: Characterization, Breeding and Utilization, 7. IntechOPen.

Newman, D. J., and Cragg, G. M. 2007. Natural products as sources of new drugs over the last 25 years. J. Nat. Prod. 70(3): 461-477.

Obadoni, B. O., and Ochuko, P. O. 2002. Phytochemical studies and comparative efficacy of the crude extracts of some haemostatic plants in Edo and Delta States of Nigeria. Glob. J. Pure Appl. Sci. 8(2): 203-208.

Rahmani, R., Beaufort, S., Alejandra Villarreal-Soto, S., Taillandier, P., Bouajila, J., and Debouba, M. 2019.Kombucha fermentation of African mustard (Brassica tournefortii) leaves: Chemical composition and bioactivity. Food Biosci. 30:100414.

Rahmani, R., Bouajila, J., Jouaidi, M., and Debouba, M. 2020. African mustard (Brassica tournefortii) as source of nutrients and nutraceuticals properties. J. Food Sci. 85: 1856-1871.

Rios, R. V., Pessanha, M. D. F., Almeida, P.
F. D., Viana, C. L., andLannes, S. C. D. S. 2014. Application of fats in some food products. Food Sci. Technol. 34(1): 3-15.

Roy, A. 2017. A review on the alkaloids an important therapeutic compound from plants. International $\mathrm{J}$. of Plant Biotechnol. 3(2): 1-9.

Sadasivam, S., and Manickam, A. 2008. Biochemical Methods, 3rd. New Age International Publishers, New Delhi, India.

Saha, J., Biswal, A. K., and Deka, S. C. 2015. Chemical composition of some underutilized green leafy vegetables of Sonitpur district of Assam, India. Int. Food Res. J. 22:1466-1473.

Santos-Buelga, C., González-Paramás, A. M., Oludemi, T., Ayuda-Durán, B., and González-Manzano, S.2019. Plant phenolics as functional food ingredients. In Adv. Food Nutr. Res. 90: 183-257.

Sodamade, A., Bolaji, O. S., and Adeboye, O. O. 2013. Proximate analysis, mineral contents and functional properties of Moringa oleifera leaf protein concentrate. IOSR J.Appl. Chem. 4(6): 47-51.

Tawaha, A. M., and Turk, M. A. 2003. Allelopathic effects of black mustard (Brassica nigra) on germination and growth of wild barley (Hordeum spontaneum). J. Agron. Crop Sci. 189(5): 298-303.

Trader, M. R., Brooks, M. L., and Draper, J. V.2006. Seed production by the nonnative Brassica tournefortii (Sahara mustard) along desert roadsides. Madroño. 53:313-320.

Trumbo, P., Yates, A. A., Schlicker, S., and Poos, M. 2001. Dietary reference intakes: vitamin A, vitamin K, arsenic, boron, chromium, copper, iodine, iron, manganese, molybdenum, nickel, silicon, vanadium, and zinc. 
J.Acad.Nutr.Diet. 101(3): 294.

Uddin, M. S., Millat, M. S., Islam, M. S., Hussain, M. S., Uddin, M. G., Siddiqui, S. A., and Ferdous, M. 2020. Exploration of in vitro thrombolytic, anthelminthic, cytotoxic and in vivo anxiolytic potentials with phytochemical screening of flowers of Brassica nigra. Future J.Pharm. Sci. 6(1): 1-9.

Uremis, I., Arslan, M., and Uludag, A. 2005. Allelopathic effects of some Brassica species on germination and growth of cutleaf ground cherry (Physalis angulata L.). J. Biol. Sci. 5: 661-665.

Xiao, Z., Rausch, S. R., Luo, Y., Sun, J., Yu, L., Wang, Q., and Stommel, J. R. 2019. Microgreens of Brassicaceae: Genetic diversity of phytochemical concentrations and antioxidant capacity. LWT - Food Sci.Techno. 101:731-737.

Zimdahl, R. L. 2007. Weed-crop competition: A review. John Wiley \& Sons.

\section{How to cite this article:}

Salem Mousbah Khalifa. 2021. Proximate Composition and Biological Assay of Two Mustard Species (Brassica nigra (L.) K. Koch and Brassica tournefortii Gouan) in Libya. Int.J.Curr.Microbiol.App.Sci. 10(01): 910-919. doi: https://doi.org/10.20546/ijcmas.2021.1001.109 